\title{
EKSISTENSIALISME IN DIE FRANSE LETTERKUNDE
}

Nooit sou die Franse jeug - en die van Europa en verder - in dié mate deur die eksistensialisme beïnvloed gewees het nie, indien hierdie filosofie in wysgerige traktate sou begrawe gelê het. Die eksistensialiste het die koning van die filosofiese verhaal, Voltaire, met sukses op sy Candide- en Zadig-pad gevolg en hulle teorieë in letterkundige werke, verhale, romans en ook toneelstukke kwytgeraak, wat baie gelees is en waaruit ook ander literatore kragte en inspirasie geput het. Omrede daarvan is daar inderdaad baie eksistensialisme in die Franse letterkunde, maar 'n eintlike eksistensialistiese letterkunde was daar nie, en 'n Eksistensialistiese Letterkundige skool het nooit bestaan nie. Ook sit hierdie eksistensialiste nie langs dieselfde vuur nie. Die Christelike eksistensialis Gabriel Marcel het op 21 April van hierdie jaar uitgevaar teen die "Sartriane" na aanleiding van die opvoering van Les Paravents, Die Windskerms van Jean Genêt in 'n Paryse staatsondersteunde teater. „Mens mag seker wees", skryf Marcel in Les Nouvelles Littéraires, „dat die hele sartriaanse parogie sal skreeu: groot meesterwerk". Voortgaande op sy distansiëring kan die literêre eksistensialiste in drie groepe ingedeel word:

1. Die Sartriane;

2. Die Christelike Eksistensialiste;

3. Die Onafhanklikes.

As Sartriane kry ons dan: Jean-Paul Sartre self, Simone de Beauvoir, Jean Genêt, Pierre Gascar en André Frénaud.

As Christelike Eksistensialiste: Gabriel Marcel, Georges Hourdin, Roger Bésus, Luc Estang, Jean Cayrol en Paul-André Lesort.

As Onafhanklikes: Raymond Guérin, Boris Vian, Colette Audry, Roger Grenier en Jean Cau, oud-sekretaris van Sartre.

Die eksistensialistiese geskiedkundige Maurice MerleauPonty (1908-1961) het gou die rug gedraai op wat hy „l'ultrabolchevisme sartrien" genoem het, terwyl net maar die kritici André Gorz, Francis Jeanson en Jean Pouillon (medewerker aan die Les Temps Modernes, tydskrif van Sartre) as ware Sartriane kan beskou word. Claude-Edmonde Magny (Histoire 
du roman français), Jean Duvignaud, Claude Roy, Manuel de Diéguez en Jean Kanapa is daarteenoor onafhanklike kritici.

Ook die eksistensialistiese letterkunde het nie ontsnap aan die ongeskrewe wet van die moderne letterkunde dat die bloeitydperk van 'n letterkundige rigting hoogstens tien jaar duur nie. So was alreeds sedert 1953, publikasiejaar van Les Gommes, Die Uitveërs van Alain Robbe-Grillet, die Nouveau Roman aan die gang, nou alreeds opgevolg deur die Roman Fable (Le Clézio) en die neo-realisme (van Troyat, bv.). In Parys blyk sake trouens nog vinniger te gaan. Sê André Brink ('n sestiger wat dit dus nie in 1970 kan bly nie) dit nie treffend in sy Pot-pourri nie: „Daar ontstaan alle kunste en modes, daar word alle filosofieë beproef, aanvaar, verwerp". Alleen die teoloë sit nou nog met die eksistensie-teologie opgeskeep.

Dit beteken egter nie dat met die verbygaan van die mode van die eksistensialisme alle beïnvloeding sommer by towerslag verdwyn het nie. Daar is veral twee letterkundige rigtings wat sterk invloede van die eksistensialisme ondergaan het. Ten eerste, die groep van die Nouveau Roman, ten tweede, die van die Avant-Garde Teater.

Die invloede wat die reeds bogenoemde Nouveau Roman ondergaan het was veral van literêr-tegniese aard. Daar word van hierdie groep se "spesiale optiek" gepraat en hy word Une Ecole du Regard, 'n Skool van die Blik genoem, weens die manier waarop sy skrywers die voorwerpe van die stoflike wêreld bekyk. Dit doen hulle met die oog van Roquentin, die held uit Sartre se La Nausée, Die Walg. Trouens is in hierdie laaste werk die mens niks anders meer as bloot 'n verhouding tussen die bewussyn en die dinge, en dié verhouding is nie altyd ' $n$ vriendelike relasie nie.

Die Avant-Garde Teater, veral die van die Ier Beckett, die Roemeen Ionesco en die Rus Adamov (almal Franse outeurs!) het die volgende elemente uit die eksistensialisme oorgeneem:

Absurditeit: die menslike lewe het geen absolute betekenis nie, die mens lewe in 'n leë ruimte: „Un vide qui se fait parole", 'n leegte wat woord word, sê Maurice Blanchot van die werk van Beckett.

Noué-heid: van die Franse participe passé „noué", geknoop, gebind, verbind, gestrik. Die mens kan vasgeval raak in sy eie fisiese wese, of in 'n lewenspatroon of in ' $n$ opinie. 
Daarmee hou sy vryheid op, en met sy vryheid sy mens-wees. Ook die dinge beperk die mens in sy vryheid en ont-menslik hom.

Eensaamheid: die mens is ' $n$ eensaamheid en daarom word sy taal soms onverstaanbaar vir sy medemens en... die toehoorder in die saal.

Natuur-loosheid: Daar is geen menslike natuur nie. Die mens is wat hy homself maak. Vry en daarom wispelturig deur die acte gratuit of onberedeneerde daad - hy het geen vaste karakter nie. $\mathrm{Hy}$ is enkel 'n eksistensie in ' $\mathrm{n}$ situasie. Avant-garde toneel bied enkel „eksistensies in situasies".

By hierdie voorafgaande opmerkings oor die Nouveau Roman en die Avant-Garde Teater moet nog toegevoeg word dat daar ook wel eksistensialistiese trekke is by "ouer" skrywers soos Anouilh en Camus. Saam met Maurice Nadeau maak ons beswaar teen die koppeling van die naam Camus aan die van Sartre. Nie in die eerste plek weens verskille wat aan die lig gekom het toe die twee in 'n spektakulêre openbare debat betrokke geraak het nie (in 1952), maar in naam van Camus se ,sainteté absurde" en die dapperheid van Sisyphos. Hulle is wel één in twee sake: hulle ateïsme en hulle absurdisme. „L'absurde naît de cette confrontation entre l'appel humain et le silence déraisonnable du monde", „die absurde ontstaan uit die konfrontasie tussen die menslike (be)roep en die onredelike stilte van die wêreld". Die groot verskil tussen Sartre en Camus is die posisie wat ons teenoor die absurditeit moet inneem. In slegs 2 woorde: teenoor l'absurdité déraisonnable (onverstandige, onredelike), la sainteté absurde, die absurde "heiligheid". Jare lank het trouens Camus met sy koerant Combat die jeug teen nihilisme gewaarsku.

\section{Die Sartriane}

Hulle pous is Jean-Paul. Gebore Parysenaar, 1905. Protestantse ma en ' $n$ katolieke pa, hy self ' $n$ neef van dr. Schweitzer van Lambaréné-faam. As 'n kleuter verloor hy sy pa deur die dood en sy ma deur 'n hertroue. Charles Schweitzer en die ouma voed die kind op. Die jong Sartre is vroeg ryp, sy groot liefde is boeke. In Les Mots, Die Woorde, 1963, skryf Sartre: „Ek had my religie gevind, niks het vir my belangriker gelyk as 'n boek nie" en woorde is die "kwintessens van die dinge". Sodanig dat hy, in dié boek waarmee hy sy bewonde- 
raars diep geskok het, homself afvra of dit hom alles nie om literatuur te doen was, of om wraak te neem op sy grootvader, wat wel sy talent erken het maar hom tog aangespoor het om liewers maar skoolmeester te word.

As 'n wysgeer is hy 'n kind van Hüsserl en Heidegger. Vir hulle was hy spesiaal in Berlyn. Onderwys sal hy gee tot in 1945, jaar van die oprigting van sy tydskrif Les Temps Modernes. In 1964 weier hy die Nobelprys.

Voor die oorlog was sy invloed nihil. Die Europese jeug het toe maar min belangstelling gehad vir Frankryk waar die demokrasie besig was om weg te sink in 'n moeras van 'n aantal ophefmakende ministeriële skandale (Stavisky en Kie.). Die jong mense van links kyk na Rusland, die van regs na Duitsland. Katolieke en Protestantse jeugbeweging probeer te "Hernieuwen" soos een van hulle tydskrifte heet. Hernuwing is die parool by elkeen, maar seker nie op die voorbeeld van Frankryk nie. Dit is ook in landsbeleid merkbaar: België, getroue vasal van Frankryk verbreek sy militêre akkoorde met dié land en slaan 'n neutrale koers in.

Die oorlog word Sartre se groot bate. Wat sou hy gewees het sonder die oorlog, dit is die vraag. Groot kom hy daaruit te voorskyn. Eers as krygsgevangene. Sy allereerste toneelstuk Bariona is in die kamp geskrywe en eers in 1964 in 'n beperkte oplaag tot beskikking van sy mede-gevangenes gestel. Later is hy weerstander, versetstryder. Wat hy voor 1940 geskryf het: L'imagination, La Nausée, die Esquisse d'une théorie des émotions, word nou eers gelees. Die publikasiedata van La Nausée spreek boekdele: Eerste uitgawe 1938, die volgende eers in 1944, maar dan begin dit goed te gaan: 1950, 1951, 1954, 1956. Na 1956 'n floute, die eksistensialisme in die letterkunde is verby. Nege jare later sal La Nausée nog eens herdruk word, maar as 'n kunsuitgawe vir bibliofiele. Die jaar daarop, in 1966 verskyn dit as 'n pocket ten behoewe van die studente van die Alliance française.

La Nausée, Die Walg speel in Bouville (stad van die modder?) waarin geredelik Le Havre, stad waar Sartre skoolgehou het, herken word. Roquentin, so pas terug van 'n wêreldreis, het hom in hierdie provinsiestad begrawe om die aldaar bewaarde dokumentasie te raadpleeg oor die lewe van die markies de Rollebon, 'n agttiende-eeuse avonturier. Roquentin hou dagboek oor sy eie doen en late in die biblioteek en 
in die kafees. Wanneer hy begin nadink oor eie lewe en werk, wanneer hy hom bewus word van sy eie eksistensie, word hy mislik. Want hierdie Walg is ook fisies, want op die oomblikke dat dit opduik is Roquentin lus om te vomeer. Oor hierdie walg hou Roquentin eindelose inwendige monoloë, wat ons wel sterk laat dink aan die van De man die zijn haar kort liet knippen van die Vlaamse magiese realis Johan Daisne (1948). Waar Sartre met Roquentin heen wil is nooit baie duidelik nie, daarvoor moet eers sy wysgerige werk gelees word, ook die wat na La Nausée tot stand gekom het. Die filosofiese aap kom eers uit die mou wanneer Roquentin met sy ewemens te doen kry. Langs hom in 'n kafee sit 'n kort mannetjie tot wie hy hom aangetrokke voel, maar: „Dit is nie simpatie wat daar tussen ons is nie: ons is eenders, dis al: hy is alleen soos ek, maar dieper weggesak in die eensaamheid as ek" want ja „ons was 'n hoop gegeneerde eksistente, opgeskeep met onsself, ons had nie die minste rede om daar te wees nie, nòg die een, nòg die ander... En ek... ek was teveel... Ek het daar vaag van gedroom om my van kant te maak. Maar selfs my dood sou teveel gewees het... Ek was teveel vir die ewigheid".

Daar kom ook geen, vriendskap tot stand met die Autodidak nie, tweede hoofpersoon van die boek, 'n halfgebildete kantoorklerkie wat hom in die biblioteek in alfabetiese volgorde geestelik kom voed. Ogier, die Autodidak, bied Roquentin selfs 'n eetmaal aan. By die kaas beken die Autodidak dat hy lid geword het van een van die sosialistiese partye uit... humanisme. Dit gee Sartre hier die geleentheid om die draak te steek met alle soorte humanisme. Dis natuurlik nog lank voor die tyd dat hy in 1946 sy L'existentialisme est un humanisme sal neerskrywe. In ieder geval, die humanisme van die Autodidak wek al dadelik die Walg van Roquentin op en dit sal die Autodidak self tot pedofilie voer, 'n praktyk wat hom vir altyd uit die biblioteek sal laat verban. Want daar is humor in die boek... Simon de Beauvoir het getuig dat Sartre in sy jeug baie van die Marx Brothers gehou het. So is daar ook die kostelike besoek aan die portrettegalery van die prominent people van Bouville in die plaaslike museum. Voor die portret van een van die staatmakers van die dorp resiteer ' $n$ dame vol bewondering ' $n$ artikel oor die man uit 'n plaaslike ensiklopedie. Roquentin staan daar langs en herkou tege- 
lykertyd iets uit 'n tydgenotelike uitgawe van Satirique Bouvillois. Die satiriese redakteur het daar vertel dat die groot man maar $1 \mathrm{~m} 53$ groot was, iets wat die skilder hoofbrekens gekos het by die komposisie. En verder het hy alle sosiale en morele ondeugde in sy „beperkte” persoontjie verenig. As volg neem Roquentin dan afskeid van die ou stadsvadere: „Vaarwel, mooi lelies, heeltemal fyntjies in julle geskilderde klein heiligdomme, vaarwel, mooi lelies, ons trots en ons rede van bestaan, vaarwel, salauds, smeerlappe". Die salauds by Sartre is die bourgeois, die bien-pensants, die weldenkendes, vol mauvaise foi, kwade trou, by voorbaat vyande van enige vorm van eksistensialisme. Roquentin is net maar aan een ding geheg: 'n grammofoonplaat. Dié laat hy by tye in sy stamkafee speel. Die lied daarop is die bekende: „Some of these days, You'll miss me honey". Dis geskrywe deur 'n Amerikaanse Jood en dit word gesing deur 'n negerin. En dit dui die twee rasse aan wat op die simpatie van Sartre sal kan staatmaak. In sy toneelstuk La Putain respectueuse, die respekvolle ligtekooi, skilder hy die situasie waarin die Amerikaanse neger geworpe is, in sy Réflexions sur la question juive, behandel hy die antisemitisme; vir 'n bloemlesing saamgestel deur Léopold Sédar Senghor, Frans digter en staatspresident van Sénégal, skryf hy Orphée noir, die swart Orpheus en lewer 'n inleiding op 'n werk oor Patrice Lumumba. Tans probeer hy 'n anti-apartheidsveldtog te loods. Literêr staan La Nausée onder invloed van die Duitse Tsjeg Franz Kafka, maar ook van Henry Miller, William Faulkner, Dos Passos en gedeeltelik ook van die surrealiste. Filosofies staan die boek natuurlik onder invloed van ... Jean-Paul Sartre!

Met Le Mur, Die Muur, eweneens 'n vooroorlogse publikasie, voel Sartre wel dat hy die sg. absurditeit en irrasionalisme van die oorlog nodig het om te kan slaag. Hierdie versameling novelles ontleen sy titel aan die hoofnovelle. Twee Spaanse rewolusionêres wag daar om teen 'n muur gefusilleer te word. 'n Soortgelyke tema sal ons dan ook na die oorlog terugvind in die toneelstuk Morts sans sépulture, Dodes sonder graf, waarin die reaksie van gevange Weerstanders en... van hulle beule teenoor foltering en dood meegedeel word.

Hoe moeilik die paaie van die vryheid in oorlog en vooroorlog bewandel word gee Sartre in sy trilogie: Les chemins 
de la liberté, Ndl. titel: De wegen der vrijheid. Eerste deel: De jaren des onderscheids (L'âge de raison), Tweede: Het oponthoud (Le sursis), d.i. die jare om en by die verdrag van München. Derde: De dood in het hart (La mort dans l'âme). Eenselfde hoofpersoon gaan deur al hierdie beproewings. Beïnvloeding deur André Gide (die van die Les Faux-Monnayeurs, Die valsmunters) en Dos Passos, deur Sartre êrens die grootste skrywer van ons tyd genoem, is duidelik. Teen al die romans van Sartre is daar hierdie groot beswaar dat ' $n$ mens eers en veral notisie moet hê van 'n aantal begrippe wat in dik boeke soos L'être et le néant; Essai d'ontologie phénoménologique, 728 bladsy in 8 punt druk opgedis word.

Daarteenoor is die sartriaanse teater heelwat deursigtiger. 'n Drietal stukke is hier reeds vermeld. Sy eerste werklike stuk is Les Mouches, Die vlieë 1943. Dis nie sy sterkste stuk nie. Orestes wat sy moeder Klutaimnestra vermoor het, is vrygespreek en sal oor Argos regeer. Dié Argos is 'n moderne stad waar die gode besig is om te sterwe, terwyl die mens hulle plek inneem.

Die meesterstuk is egter Huis clos, Met geslote deure, 1945. Vooraf moet egter nog gesê word dat die teater van Sartre toneeltegnies nog konvensioneel is. Tematies is daar 'n wegbreek van die tradisionele boulevard-toneel-ontwerp, die bekende driehoeksgeval en Sartre lewer die genoemde aantal ideë aan die Avant-garde toneel. 'n Hernuwer van die drama is hy nie.

In 'n hotelsitkamer waarvan die deure gesluit is, ofskoon dit later sal blyk dat hulle tog oop is, wag 3 persone op hulle straf in die hel, want hulle is dood. Die een was 'n vaandelvlugtige, die ander 'n straatvrou en die derde, ook ' $n$ vrou, het haar kind vermoor. Hulle beken vir mekaar hulle misdade en dit gee 'n oomblik verligting. Maar gou duik onenigheid op, omdat die een hom tog nog beter ag as die ander en met veragting neerkyk op die ander se misdaad. Daarom moet hulle uiteindelik tot die besef kom dat die hel: C'est les autres, dis die ander. Dis die blik van die ander op ons skandelike lewensgeheim en hierdie kwelling is erger as alles wat die hel nog kan bied. Ewig sal die personages van Huis clos met mekaar opgeskeep bly, ewig in hierdie hotelsitkamer, décor van hulle hel: „Slimstreke help nie meer nie, ontsnapping ook nie: 'n mens is soos die ander jou sien: dis dan nou 
die hel. Dit kon ek nooit geglo het nie... Onthou julle nog: die swawel, die brandstapel, die rooster... O! Wat 'n grap! Die rooster is nie nodig nie, die hel, dis die ander".

$\mathrm{Ja}$, ook in al die ander toneelstukke is die mens ten prooi aan die mens. In Die vuil hande is politikusse die slagoffer van politikusse. Kommunistiese realisme en kommunistiese idealisme kom in konflik. In Les Séquestrés d'Altona is die mens ten prooi aan die mens wat hy self is. Frantz, eers beskermer van die Jode en later Nazi, sluit hom op in selfkwelling en hoop deur wroeging en berou oor sy misdade katarsis te vind. Maar tevergeefs, alleen selfmoord is 'n uitkoms vir hom want die mens het nie die mag om te vergeet en nog minder om sy foute te herstel nie. Want God, die vergewer van alle sondes, is dood. En as jy dit nie glo nie, kom en kyk na Le Diable et le Bon Dieu. Goetz is daar die eensame mens, alleenheerser oor sy lot in 'n wêreld sonder God. God het belet dat die mense mekaar sou bemin, God moet geloën word opdat die mense sou kan lewe. Die bestaan van God is onverenigbaar met die Absolute Vryheid van die mens.

Die toneelcarrière van Sartre word afgesluit met 'n bewerking van Les Troyennes, die Trojaanse vrouens van Euripides.

Sartre is nou eintlik uitgeskrywe. Hy sal egter voortgaan met skryf "uit gewoonte" sê hy in Les Mots. Hy is nou al aan 'n sewende deel van Situations. 'n Veelseggende titel: dink maar aan die begrip van die geworpe-wees-in-'n-situasie. Hierin gee hy sy opinie oor 'n hele aantal „problemes", vraagstukke. Deel V het oor die Colonialisme et néo-colonialisme gegaan, VI en VII oor die probleme van die Marxisme. Na Les Mots het alleen maar sy Oeuvre romanesque of versamelde romans verskyn en La Transcendance de l'Ego; Esquisse d'une description phénoménologique, 'n soort reduksie van L'être et le néant, met inleiding, notas en toevoegings nie van homself nie, maar van ene Sylvie Lebon. Dis trouens maar net 'n deel in ' $n$ reeks: Bibliothèque des textes philosophiques. Sartre is nou oortuig van die „onmag van alle literatuur ten aansien van die onmoontlike verlossing van die mens". Hy is nou net maar 'n man „wat nie weet wat om te maak met sy lewe nie" skryf hy in Les Mots, 1963.

Simone de Beauvoir is van haar jeug af 'n vriendin van Sartre. Haar verdienste is dat sy probeer het om doelbewus 
'n eksistensialistiese etiek te skrywe, maar dit het maar 'n Morale de l'Ambiguité, 'n Moraal van die dubbelsinnigheid geword. Diep nadenkend oor haar eie bestaan het sy 'n aantal romans geskrywe waarin ons haarself en ook wel Sartre herken. In L'Invitée, Die genooide, van 1943, word 'n vroulike gas opgeneem in ' $n$ jong pseudo-gesin. Die jong man word verlief op haar en tog word dit geen Raciniaanse verhaal van jaloersheid nie. Alleen maar: 'n Indiwiduele bewussyn het in botsing gekom met ' $n$ ander indiwiduele bewussyn, 'n eksistensie het 'n ander eksistensie kom onderdruk.

Die bloed van die ander, 1944, speel net soos Sartre se Dodes sonder graf in die kringe van die oorlogstydse verset. Maar hier vra die leier hom af watter morele reg hy het om mense in die dood te stuur.

In Alle mense is sterflik het die held in die jaar 1279 'n towerdrankie gedrink waardeur hy onsterflik geword het. Maar die voorreg geval hom nie. Die begrip risiko (gevaar loop) en engagement (inset) het uit sy lewe verdwyn. Die dood maak inderdaad ' $n$ wesenlike bestanddeel van ons lotsbestemming uit. Die dood laat ons iets doen voor dit te laat is. Is ons onsterflik dan behoort ons heeltemal niks te doen nie.

Simone se meesterwerk is egter Les Mandarins, Ndl. titel: De Mandarijnen, 1954. Hiermee bring sy die tragiese boodskap van die bankrotskap van die linksgesinde Franse intellektueel van na die bevryding. „Wat was de bevrijding mooi toen het nog oorlog was", het Vrij Nederland, koerant van Nederlandse versetsliede geskryf. Perron is die intellektueel wat homself afvra wat hy eintlik was. Hy kry die antwoord: „dat hy 'n Franse intellektueel was, bedwelm deur die oorwinning van 1944 en wat deur die gebeurtenisse teruggevoer is tot die heldersiende besef van sy nutteloosheid". Dubreuilh dan wens nog steeds „die oorwinning van die kommunisme al besef hy dat hy nooit in 'n kommunistiese wêreld sou kan lewe nie". Hulle sal wees soos die Mandaryne uit China, waarnemers en kroniekskrywers van wat onder hulle en rondom hulle gebeur. As aktiewe kragte het hulle waardeloos geword.

In outobiografiese werke soos La force de l'âge en La force des choses, hierdie laaste 'n soort oorlogsdagboek, ondersoek Simone de Beauvoir die "geval Beauvoir". Heel merkwaardig is haar eksistensialistiese gedagtes oor die vrou. Dié stel sy in Le deuxième sexe as volg: Daar is stryd tussen mens 
en mens (i.c. tussen man en vrou). Die mens (i.c. die vrou) is wat van hom (i.c. haar) gemaak word. Die mens (i.c. die vrou) is geen prooi van een of ander natuur (i.c. die vroulike natuur) nie, maar van die medemens (i.c. die man). Die vrou is dus wat die man van haar maak.

Die moeder van Jean Genêt was blykbaar so 'n tipe vrou. Sy was ongehuud en het die kind in die steek gelaat. Jean word 'n dief en 'n misdadiger, 'n tronkvoël wat om die waarde van sy letterkundige werk na 'n veroordeling tot lewenslange hegtenis deur die staatspresident begenadig word. $\mathrm{Hy}$ is ' $\mathrm{n}$ koopman in verdowingsmiddele en bowendien ' $\mathrm{n}$ homoseksueel. In 'n interview wat in Randstad, die tydskrif van Hugo Claus, verskyn het, sê hy dat hy persoonlik ,zeer veel" aan die homoseksualiteit te danke het. „Als men dit als een vloek wil beschouwen, dan moet men dat zelf weten, maar ik beschouw het als een zegen ... Het heeft een schrijver van me gemaakt en me in staat gesteld de mensen te begrijpen".

Hierdie man is heilig verklaar... nie deur die Roomse kerk nie, maar deur Jean-Paul Sartre. Dié skryf 'n inleiding op sy versamelde werke: Saint Genêt, comédien en martyr, Sint Genesius, teaterman en martelaar. Martelaar soos Genesius van ouds wat hom tydens 'n voorstelling tot die Christendom bekeer het. Maar martelaar natuurlik van die samelewing van die salauds, wat oor al die dinge, ten eie behoewe, nog heelwat bekrompe gedagtes het. Heilige, omdat hy self beweer ,heiligheid is my doel... ek wil dat al my dade my na hom lei wat ek nie ken nie". In sy romans en teaterstukke lewer Genêt ons die mistiek van die volmaakte misdaad. Doen hy dit nie, dan skilder hy ons die „Verkeerde Weereldt": Die Meide wat die rol van hulle meesteresse speel, of Die Negers wat hulle as blankes verklee. Sy meesterwerk is Die Balkon. Die Balkon is die naam van die bordeel van Madame Irma. Daar kom die bewoners van die stadjie om hulle onder te dompel in 'n wêreld van illusies. Hulle verklee hulle daar in invloedryke persone: biskop, regter of generaal en oefen hierdie ampte uit geholpe deur Madame Irma wat as koningin optree. Terwyl die skyn-prominensies met hulle ernstige spel besig is, is buite 'n rewolusie aan die gang. Die polisiehoof, wat 'n vriend van Madame Isma is (hy is baie ongelukkig omdat niemand 
hom wil naboots nie) kom binne om te vertel dat, aangesien die koningin vermoor is, hy dringend 'n koningin en ook nog 'n biskop, 'n regter en ' $n$ generaal nodig het om die rewolusionêres te lei. Die simulante kry nou die geleentheid om hulle rolle in die werklikheid te speel, maar daar misluk hulle deerlik omdat hulle nou niks meer het om oor te droom nie. Bowendien word hulle deur die rewolusionêres uitgeken wat hulle self afvra of die rewolusie wel plaasgevind het. Werklikheid ontneem alle waarde aan die lewe, alleen dic droom is lewe en op die einde doof Madame Irma die ligte uit in die bordeel en maan ons om huis toe te gaan "waar alles selfs valser sal wees as hier".

Les Paravents, Die Windskerms, so genoem na die windskerms wat op die verhoog opgestel staan, is hierdie jaar in die Odéon, die Théâtre de France opgevoer. Dit bied 'n weersinwekkende beeld van die Algerynse oorlog. Wanneer in die tweede bedryf, valskermsoldate hulle sterwende offisier die grofste beledigings toestuur, het Saint-Cyriens, studente van die leërgimnasium na die verhoog opgemarsjeer en daar slaags geraak met die akteurs-parasjutiste. Gabriel Marcel het dus nie alleen gestaan in sy protes teen hierdie lastering van die eer van die Franse soldaat nie. Die sindikaat van die Franse toneelspelers het geprotesteer, maar die algemene gevoel van die toneelkritici in Parys is, dat die eksistensialistiese teater hier beslis te ver gegaan het.

Die romanskrywer Pierre Gascar beskryf onder invloēd van Franz Kafka obsederende, onlogiese en eksistensialistiese gedrag van diere wat aan die sadisme van die mens blootstaan. In Les Bêtes vertel hy ons dat die mens wreed is en nie die minste eerbied vir die lewe en medelye vir swakheid het nie. 'n Kalf wat deur die slagter stukkend gekap word, perde wat wegvlug vir 'n bomaanval, katte en honde wat trou bly aan meesters wat hulle mishandel het, soveel aanklagte teen die mens wat sy wêreld in stand hou deur onskuldiges te dood. 'n Sterker boek is Soleils, Sonne waarin Spaanse werkers mal word van die verblinding wat veroorsaak word deur die skyn van die son op die spierwit wande van 'n steengroef.

André Frénaud word die Sartre van die poësie genoem. 
Die leser kan self oordeel:

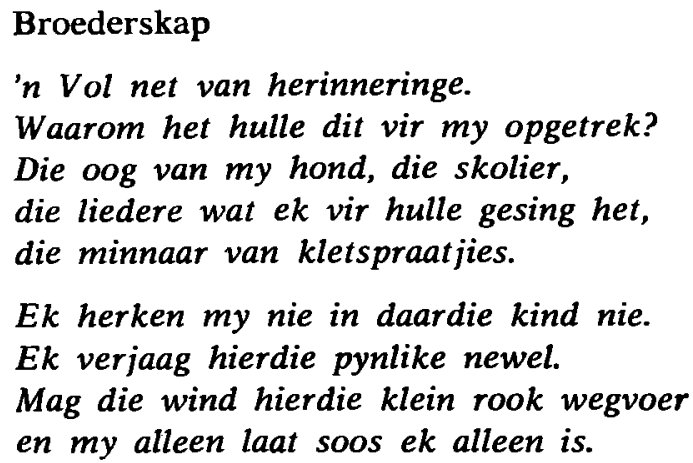

Ek herken my nie in daardie kind nie.

Ek verjaag hierdie pynlike newel.

Mag die wind hierdie klein rook wegvoer

en $m y$ alleen laat soos ek alleen is.

Nogtans sou ek dit wil vat wanneer ek dit vlug, terug saamstel die hele mens tot op my, ouderdom, hy wat sy plek aanvaar het en hulle spele.

$O$ warmte wat my vandag seer maak.

Jammerte oor julle en my, aangesien dit nie toegelaat is, Broers,

van te wees een enkele broederlike wese nie, voor die koel bors van die nag

in die eenheid van ons moeder.

\section{Die Christelike eksistensialiste}

By die Christelike eksistensialiste wat hoofsaaklik katoliek of sterk deur die katolisisme gekondisioneer is, is die grootkop Gabriel Marcel. Alleen al met die titel: Etre et Avoir staan sy teoretiese werk teenoor die groot werk van Sartre: L'être et le néant. Vir Marcel eksisteer die mens, ja, maar alleen dan wanneer hy homself oortref deur ' $n$ volgehoue inspanning. In daardie inspanning herken die mens die aksie van 'n goddelike prinsipe, waaraan hy deel het. „Die siel bestaan deur die hoop; die hoop is miskien die stof self waaruit ons siel gemaak is". Oor hom het Friedrich Hoefeld 'n diepgaande studie geskrywe: Der christliche Existenzialismus Gabriel Marcels. In sy teater bring Marcel mense wat daar egter nie in slaag om daar die volgehoue inspanning om hulleself te oortref te lewer nie. Dit is karakters met verskeurde gewetens wat ons laat terugdink aan die van François Mauriac en Julien Green. 
Marcel se eweknie Georges Hourdin skryf veral katoliekeksistensialistiese essays oor Françoise Sagan, Simone de Beauvoir en ander moderne outeurs.

Roger Bésus is ook 'n outeur van die sielestryd. Hy staan onder invloed van Dostojewski en die Christendom. Hy is die skrywer van Refus, Le Scandale, Les abandonnés en La vie au sérieux. Luc Estang doen aan selfontleding en is verwant aan Bésus in die beskrywing van sielskonflikte. By Jean Cayrol voel die mens in sy angs dat hy tot ' $n$ ander ras behoort as die van die mense, sy gebare en handelinge het 'n ander draagwydte en betekenis as wat die wêreld aan hulle toeken. Die hemel gryp in die lewe op aarde in met tekens wat misterieus bly. Paul-André Lesort skryf Les Reins et les Coeurs, Die Harte en die Niere, 1947, waarin hy trouens probeer om die harte en niere van sy helde te deurgrond.

Hierdie reeks name bewys dat die religieuse roman in Frankryk tog nog 'n kans maak. Hy sal hom egter nog van heelwat eksistensialisme moet ontmaak en 'n nuwe Bernanos lê nog nie in die verskiet nie, al het Luc Estang en Jean Cayrol tog sy invloed ondergaan.

\section{Die onafhanklikes}

Met die onafhanklikes word die rekord weer minder mooi. Die alreeds oorlede Raymond Guérin beweeg hom op die randjie van die pornografie. Vir hom is die eksistensie van die mens louter fisiologies bepaal. Hy is 'n wese wat net maar leef om sy onversadigbare liggaam te voed. In Wanneer die einde kom beskryf hy die langsame doodstryd van sy vader wat sterf aan 'n anuskanker. L'Apprenti, Die leerjonge, is 'n onanis en masturbant. Alles by Guérin is vieslik, laag en gemeen. Boris Vian bedek menslike wanhoop deur humor. Die skuim van die dae, Die Herfs in Peking is sy belangrikste werke. Ook hy is alreeds oorlede. Colette Audry het wel haar verhale aan Sartre opgedra, maar sy verskil van hom deur 'n soort Camusiaanse lewensmoed. Na Aux Yeux du Souvenir, In die ö̈ van die herinnering, 1947, bly sy stil tot in 1962, wanneer sy verras met 'n ontroerende verhaal oor 'n dame en haar hond: Derrière la Baignoire, Agter die badkuip. Roger Grenier skryf met humor, in die styl van Boris Vian oor die 
awenture van die oorlogstydse weerstand. Jean Cau, oud-sekretaris van Sartre skryf half-humoristies, half-satiries oor Les Paroissiens, 1958. Hierdie parogiane is die gemeentelede van die kafeekelderparogie van Saint-Germain-des-Près, waarvan ons meer gehoor het as van die ware eksistensialiste self. Nou gaan Grenier meer en meer die rigting van Genêt op.

\section{Pessimistiese ateisme}

Die ateïsme van Sartre en sy trawante verskil wesenlik van dié van die agttiende eeu. Die ateïsme van die "Verligte" eeu, soos beliggaam veral in Diderot met sy Encyclopédie was 'n blymoedige, optimistiese ateïsme. Die wetenskap, triomfantelik in die opmars, sou al die bygelowe van die mens verdryf, en die hemel na die aarde bring. Hierdie blyspel het 'n treurspel geword: die treurspel van die humanisme sonder God: La tragédie de l'humanisme sans Dieu soos Henri de Lubac dit noem. Hierdie pessimistiese ateïsme maak ook die onderwerp uit van Moderen Literature and the death of God van Charles I Glicksberg. Glicksberg voer ons terug na Nietzsche, wat die moord op God gepleeg het. Maar ook dit was vir die eksistensialistiese ateïste 'n absurde bewering: God is nie dood nie, Hy het nie eers bestaan nie. Ook het die verwagte Uebermensch nie opgestaan nie. Aan niemand dus, ook nie aan die "mislukte God" wat die mens is, kan die skuld gegee word vir die "geworpe-wees-in-die-aardse-situasie nie". Daar is selfs nie 'n sondebok waarop 'n bietjie afgereageer kan word nie.

En nou mag Thielicke wel beweer dat ondanks die dood van God, die soeke na God nog voortgaan en mag Beckett selfs spot met die godsoekertjies in En attendant Godot, Terwyl ons wag op godjie, feit bly staan dat die eksistensialiste al meer en meer in pessimisme weggesink het. Bereid om alle absurditeit te aanvaar is hulle nie bereid om ook die absurde feit te aanvaar dat God sou kan bestaan, soos een van hulle dit eens gestel het. Al gaan hulle sover as Camus van te verklaar dat „Kuns 'n glans en 'n heerlikheid weergee wat onvermoeibaar 'n God verkondig, wat nie bestaan nie", van hulle aprioristiese stelling is hulle nie weg te ruk nie. En ook hulle inset of engagement maak hulle nie gelukkig nie.

André Espiau de La Maëstre, direkteur van die Institut 
français van Wenen, skryf in sy meesterlike werk Der Sinn und das Absurde: ,So ehrlich und ernstzunehmend der existentialistische Wille zum irdischen Engagement auch sein mag, bleibt jedoch die existentialistische Psyché in ihren tiefsten Schichten von Pessimismus einer verzweifelten Einsamkeit, vom wütenden oder morbiden Bewusstsein der Scheiterns behaftet" (S. 335). Ons staan hier inderdaad ver van die optimisme van die ateïste van die Aufklärung.

„Ähnlich ist es bei Malraux", skryf Espiau verder: „Die menschliche Seele wurde, nachdem sie sich des Todes Gottes bewusst geworden war, wortwörtlich „,verrückt" und ihre dauernde Qual ist eben jetzt jene „wütende Sehnsucht nach dem Jenseits", einem Jenseits, das es überhaupt nicht gibt" (S. 341 ).

\section{Die strooihalm van die mite}

Hierdie wütende Sehnsucht nach dem Jenseits het ateïste daartoe gedryf om hulle aan een of ander mite vas te klou. Vir Malraux soos destyds by Drieu de la Rochelle is dit die mite van die kuns, vir ander die van seks. (Malinowsky: Sex, Culture, and Myth). Hierdie mites is neo-mites en soos Paul van Ostaijen gesê het: aan elke neo ontbreekt etos. Eienaardig is wel, dat die ateïstiese eksistensialiste mites soek, terwyl die theïstiese eksistensialiste of eksistensieteoloë: Bultmann, Barth, Braun, Bartsch en konsorte Entmythologisierung vooropstel! Teen hierdie Entmythologisierung van Bultmann en Kie. het Wilhelm Knevels opgetree met sy interessante boek: Die Wirklichkeit Gottes, Stuttgart, 1964:

„Ohne das erlebte und geglaubte Erscheinen der Gottheit in der Welt gibt es keinen Mythos. Wer es streicht, verliert den Mythos, die Religion und den Glauben" (S. 45).

"Immerhin zeichnet sich heute eine allmähliche, aber sichere Rückkehr zum echten Mythos ab, eine Neufindung dessen, was der Mythos wirklich will. Man kann in der Stickluft der Weltlosigkeit, Wert-losigkeit und Gott-losigkeit, bei der Abschnürung und Eingepresstheit in die eigene Person und Existenz nicht mehr atmen. Die ausgeschalteten, missachteten und geleugneten Wirklichkeiten und Mächte erheben sich wieder. Der Mythos war nur scheintot. Er wird sich wieder lebendig zeigen. ... Von Gott kann nur geschwiegen - oder 
mythisch geredet werden" (S. 74-75).

Die moderne letterkundige mite is egter bloot 'n poging om iets te bewys op grond van 'n heidense "openbaring". Mens sou kan sế: mites as Ersatz-openbarings.

Wat nou i.s. teologie die teengestelde aksie, die van die Entmythologisierung, betref, is dit natuurlik die bedoeling om die Skrif tot die moderne menslike vlak te laat afdaal en daarom moet die sg. mitologiese gedeeltes daarvan oor die hoof gesien word. Die almagtige God word aldus beroof van die glans van sy wonderwerke.

Die ongelowige eksistensialis mitologiseer dus, terwyl die gelowige eksistensialis ont-mitologiseer. As dit so is, dan kan goed bedoelde pogings soos die van Carl Michalson met sy Christianity and the Existentialists om Christendom en existensialisme te versoen, maar laat vaar word.

\section{Chaos en skepping}

As ons nou eerlik wil besluit dan moet ons erken dat een van die min en dan nog gebrekkige bates van die eksistensialisme presies hierdie mitologiseringsneigings is. Nog ' $n$ bate is, dat die eksistensialisme as 'n irrasionalisme die positivisme, en met hom, absurd genoeg, die negentiende-eeuse ateïsme 'n gevoelige hou toegedien het. Wie deur die mikroskoop kyk sien hoe die wit en die rooi ateïstiese mikrobes genaamd A.18, A.19 en A.20 besig is om mekaar op te vreet. A staan vir Ateïsme, die getalle vir die eeue...

'n Derde interessante verskynsel, wat wel moeilik 'n bate kan genoem word, is dat die existensialisme 'n interessante chaos geskep het. Hier moet ons deur 'n makroskoop kyk, indien so ' $n$ instrument ooit bestaan. Is dit ' $n$ nuwe voorwêreldlike chaos waaruit 'n nuwe skepping kan gebore word? Jacques Maritain in sy Court Traité de l'existence et de l'existant, Parys, 1947, skryf op p. 214 en 217: „Die ateïstiese eksistensialisme besit ' $n$ wellig baie verwarde en teleurgestelde, maar tog diep ervaring van die menslike vryheid. Dit bied 'n sorgvuldige uitgewerkte metafisiek van die conditio humana ... Sulke wysbegeerte skep 'n lugleë ruimte, waaruit op een of ander tyd 'n ware Synsmetafistiek kan opduik".

Hoe nou so 'n Synsmetafisiek deur ateïste kan geskep word of hoe sg. Christelike eksistensialiste dit met behulp van 
'n ontmitologiseerde bybel gaan verwesenlik, dit is die vraag.

Maar God, Hy is nie dood nie, het die eerste Woord gehad en dit was skepping en ook die laaste, nie allerlaaste nie, want $\mathrm{Hy}$ is ewig, en dit was opstanding.

Daarom is dit absurd dat alles absurd sou wees, soos die tagtigjarige André Maurois dit nog in September van hierdie jaar skrywe in 'n Oop brief aan 'n jong man, gepubliseer in die Revue de Paris.

Iets het sin en dit is, om die taal van die eksistensialiste te praat, ons geworpe-wees deur God in 'n wêreld geskape deur Hom. Bemoedigend klink daarom die kort gedagte van Der Rembrandtdeutsche Julius Langbehn, skrywer van Der Sinn des Ganzen:

„Ist der Chaos da,

Ist die Schöpfung nah".

Maar moet ons daaraan nie toevoeg nie: Alles sal regkom, as die Christen sy plig doen?

P.U. vir C.H.O.

A. A. F. Teurlinckx.

\section{Bibliografie:}

Die bibliografie oor die eksistensialiste is natuurlik onoorsienbaar. Oor Sartre alleen, op datum van Januarie 1966, in Frans, 47 titels. Die meeste werke van die eksistensialiste self is uitgegee te Parys by Gallimard, Seghers, Plon of Nathan. Hulle word hieronder nie meer vermeld nie.

Essensieel, resent en maklik verkrygbaar is:

Albérès, R.-M.: Histoire du roman moderne. Paris, Albin Michel, 1962. Albérès, R.-M.: Jean-Paul Sartre. Bruxelles-Paris, Editions universitaires, 1953 (7e édition, 1965).

Arntz, J. T. C.: De liefde in de ontologie van J.-P. Sartre. L'amour dans l'ontologie de J.P. Sartre; Proefskrif. Nijmegen, K.U., 1960.

Brink, A. P.: Pot-pourri; sketse uit Parys. Kaapstad, Human \& Rousseau; 1962.

De Boisdeffre, P.: Les écrivains français d'aujourd'hui. Paris, Presses universitaires de France, 1963.

Du Plessis, P. G. W.: Opskorting van die etiese? Die ontwerp van die etiese behore by M. Heidegger, K. Jaspers, J.P. Sartre en S. de Beauvoir; Proefskrif. Potchefstroom, P.U. vir C.H.O., 1962, tans gepubliseer by Pro Rege-Pers Beperk, Potchefstroom.

Espiau de la Maëstre, A.: Der Sinn und das Absurde; Malraux, Camus, Sartre, Claudel, Péguy. Salzburg, Müller, 1961.

Frois, E.: Jean-Paul Sartre adapte Les Troyennes d'Euripide. Le français dans le monde. Paris, No. 34 - juillet-aoat 1965, p. 53. 
Genêt, J.: Interview met Playboy; Vertaling John Vanderbergh. Randstad 9. Amsterdam-Antwerpen, 1965, p. 6-15.

Haffter, P.: Die Franse avant-garde toneel. Tydskrif vir Letterkunde, Johannesburg, Nuwe Reeks, jg. 3, Nr. 1, Februarie 1965, p. 42-48.

Hoefeld, F.: Der christliche Existenzialismus Gabriel Marcels; eine Analyse der geistlichen Situation der Gegenwart. Zürich, ZwingliVerlag, 1956.

Ibert, J.-C.: Jean-Paul Sartre and the secrets of his childhood. Courrier de France. Le Cap, June 1964, no. 5, p. 12-14.

Knevels, W.: Die Wirklichkeit Gottes. Stuttgart, Calwer Verlag, 1964.

Koch, H. G.: Abschaffung Gottes? Der materialistische Atheismus als heutige Existenzform. Stuttgart, Quell Verlag, 1961.

Magny, Claude-Edmonde: Histoire du roman français. Parris, Editions du Seuil, 1950.

Malinowski, B.: Sex, Culture, and Myth. New York, Harcourt, Brace \& World, 1962.

Marcel, G.: Le Procès de Jean Genêt. Les Nouvelles Littéraires. Paris, 21 avril 1966.

Maurois, André: Lettre ouverte à un jeune homme. La revue de Paris. Septembre 1966, p. 1-13.

Michalson, C.: Christianity and the existentialists. New York, Scribners, 1956.

Moeller, Ch.: Littérature du XXe siècle et Christianisme. Doornik, Casterman, 1960.

Nadeau, M.: Le roman français depuis la guerre. Paris, Gallimard, 1963.

Nota, Y. H.: Gabriel Marcel. Baarn, Het Wereldvenster, 1965.

Parain-Vial, Jeanne: Gabriel Marcel et les niveaux de l'expérience. Paris, Editions Seghers, 1966.

Pronko, L. C.: Avant-Garde; The Experimental Theatre in France. London, Cambridge University Press, 1962.

Roubiczek, P.: Existentialism; for and against. London, Cambridge University Press, 1964.

Simon, P.-H.: Théâtre et Destin; La signification de la renaissance dramatique en France au XXe siècle; Montherlant, Giraudoux, Anouilh, Mauriac, Camus, Sartre, Claudel, Salacrou. Paris, Armand Colin, 1959.

Snyman, W. J.: Geskiedenis en heilsgeskiedenis by Bultmann. Perspektief, Potchefstroom, jg. 2, nrs. 3 en 4, 1964.

Van der Merwe, N. T.: Die Eksistensialisme. Potchefstroom, P.U. vir C.N.O. Ongepubliseer, in hs., 1966 